\title{
Understanding Megaliths of Pennagaram Taluk, Dharmapuri District
}

\author{
Mutharasu Anbalagan ${ }^{1}$, Don Wesley ${ }^{2}$, V. Pradeep ${ }^{3}$ \\ ${ }^{1}$ Archaeologist, Dharmapuri \\ ${ }^{2}$ Archaeologist, Chennai \\ ${ }^{3}$ Archaeological Survey of India, Chennai \\ arasumuthu000@gmail.com
}

\begin{abstract}
Since the discovery of Megalithic burial by Babington in 1823 in Kerala, hundreds of Megalithic burials were explored and excavated all over India. In the northern part of Tamil Nadu, the Middle Cauvery Basin is very rich in archaeological vestiges dating from various periods. Burial with the superstructure in the form of Cairn-Circle or Dolmen was a common feature dating from Iron Age to the Historical period and are collectively referred to as Megalithic Burial in India. To understand the spatial pattern and the effect of geography and geology of an area on the Megalithic burial practice, the taluk of Pennagaram was selected. This article is mainly related to the finding from 10 newly discovered Megalithic burial sites from Pennagaram taluk, which forms part of the Middle Cauvery Basin. In this article, with the help of Google map and Geological map an understating of the spatial pattern and why Megalithic builders of this region selected the place where the present burials are noticed.
\end{abstract}

Keywords: Cairn Circle, Cist, Megaliths, Pennagaram, Vandalism. 


\section{Introduction}

'Megaliths' are monuments constructed out of large stones and were the burial practice of various cultures dating from the Iron Age to the Historical period. The term 'Megalith' is derived from the Greek word 'megas', which means big or great and 'lithos' means stone. Thus, Megaliths refers to the monuments constructed out of large stones for the memory of deceased people. These Megalithic burials are spread over a large area, including the Deccan plateau, Peninsular India, Vindhya ranges, some parts of Jammu and Kashmir and the Northeastern part of India. Precisely, in Tamil Nadu, the Sangam literature such as Narrinai, Purananuru, Pathirrupattu and Manimekalai has mentioned these various types of burials and its ritual practices in ancient Tamil Nadu. Morphologically these burials were classified as Cairn circle (Kal Vattam), Dolmen (Kal Tittai), Cist burial (Kal Patukkai), Urn burial (Mutumakka! Tāli), Menhir (Kutukkal), Hat stone (Topikkal) and Umbrella stone (Kuḍakkal). Research on Megaliths was undertaken by various scholars like Babington (1823), Alexander Rea (1888), Wheeler (1948), Gururajarao (1972), Leshnic (1974), Sundara (1975), K. Rajan (2000) and Selvakumar and Mohanti (2002) from the colonial period. The chronology of Megaliths is still controversial after two centuries of research on Megalithic burials. The earliest date of Megalithic burial is $9^{\text {th }}$ century BCE obtained from an archaeological site called Adichanallur in Tamirabarani river valley and the youngest Megaliths are dated back to $7^{\text {th }}$ century CE from Siruthavur in the northern part of Tamil Nadu. Most of the Megalithic burials from South India are secondary burials in nature where the burials contain few remains of the deceased person instead of the whole body. These burials remain in the form of grave goods like beads, iron objects and potteries. Often these potteries include Black-and- Red ware, All Black ware and Red slipped ware and Red Ware.

The present study area geographically comes under Middle Cauvery Basin and lies between the Western Ghats and the Eastern Ghats and forms an administrative division in Pennagaram taluk of Dharmapuri district (Fig.1), Tamil Nadu. Initial exploration work was conducted by Robert Sewell in 1882, when he discovered one dolmen at Ajjampatti in Pennagaram taluk, which he published in Antiquarian 
Remains in the Presidency of Madras in 1882. After the establishment of the Archaeological Survey of India in 1861, many archaeological exploration works were conducted in Pennagaram Taluk and numerous archaeological sites have been reported from this study area. These findings were reported in the reputed journal of IAR- Indian Archaeological Review 1988-1990. Subsequently, in 1997, Dr K. Rajan had conducted extensive field work in the Dharmapuri district and reported several archaeological sites ranging from the Iron Age to the Historical period, which was reported in Catalogue of Archaeological sites in Tamil Nadu (Rajan. K. 1997).

These studies have reported archaeological vestiges dating from Iron Age to the Modern Period. The present study is mainly focused on Megalithic Burials, their location, exploitation of raw material and study the spatial pattern of burials. This article is based on 10 newly discovered Megalithic burial sites from Pennagaram taluk.

\begin{tabular}{|l|l|l|l|l|}
\hline $\begin{array}{c}\text { SI. } \\
\text { No }\end{array}$ & Name of the Site & Latitude & Longitude & Burial Types \\
\hline 1 & Ajjanahalli & $12^{\circ} 1^{\prime} 50^{\prime \prime} \mathrm{N}$ & $78^{\circ} 48^{\prime} 44^{\prime \prime} \mathrm{E}$ & Cairn-Circle \\
\hline 2 & Eriyur & $12^{\circ} 0^{\prime} 17^{\prime \prime} \mathrm{N}$ & $77^{\circ} 47^{\prime} 17^{\prime \prime} \mathrm{E}$ & Cairn-Circle \\
\hline 3 & Kurkampatti I & $12^{\circ} 1^{\prime} 52^{\prime \prime} \mathrm{N}$ & $77^{\circ} 48^{\prime} 53^{\prime \prime} \mathrm{E}$ & Cairn-Circle \\
\hline 4 & Kurkampatti II & $12^{\circ} 1^{\prime} 36^{\prime \prime} \mathrm{N}$ & $77^{\circ} 47^{\prime} 47^{\prime \prime} \mathrm{E}$ & Cairn-Circle \\
\hline 5 & Kurkampatti III & $12^{\circ} 1^{\prime} 37^{\prime \prime} \mathrm{N}$ & $47^{\circ} 47^{\prime} 28^{\prime \prime} \mathrm{E}$ & Cairn-Circle \\
\hline 6 & Pattakarankottai & $12^{\circ} 1^{\prime} 29^{\prime \prime} \mathrm{N}$ & $77^{\circ} 48^{\prime} 27^{\prime \prime} \mathrm{E}$ & Cairn-Circle \\
\hline 7 & Periyavathalapuram & $12^{\circ} 3^{\prime} 41^{\prime \prime} \mathrm{N}$ & $77^{\circ} 50^{\prime} 05^{\prime \prime} \mathrm{E}$ & Cairn-Circle \\
\hline 8 & Sidumanahalli & $12^{\circ} 0^{\prime} 43^{\prime \prime} \mathrm{N}$ & $77^{\circ} 50^{\prime} 22$ & Cairn-Circle \\
\hline 9 & Solapadi & $12^{\circ} 0^{\prime} 8^{\prime \prime} \mathrm{N}$ & $77^{\circ} 49^{\prime} 2^{\prime \prime} \mathrm{E}$ & Cairn-Circle \\
\hline 10 & Thanda & $12^{\circ} 01^{\prime} 41 " \mathrm{~N}$ & $77^{\circ} 47^{\prime} 05^{\prime \prime} \mathrm{E}$ & Cairn-Circle \\
\hline
\end{tabular}

Table 1: List of Megalithic burial sites from Pennagaram taluk, Dharmapuri District. 


\section{Location of The Burials}

The Megaliths are found generally on the slopes of hills or elevated parts and the foot hills of the non-productive lands. In the Pennagaram taluk, the Megaliths are found very close to the river streams, dry lakes, whereas in some cases, they are also found to have been erected in dry areas where the rocky outcrop is exposed. The contemporary people have selected the places for constructing these burials were basically where the raw materials are easily available at some approachable distance from the habitation area. The majority of burials from this taluk are situated in the foothills and slope of the hills, dense forest, and also some of them are found in river banks.

\section{The exploitation of Raw Material for Burial Erection}

The Megalithic people have selected locally available raw materials for the erection of these burials and the reason could be for the easily transportable stones for burial construction. The present location of the graves indicates that the raw materials were available within a distance of one or two kilometres. These stones were used as undressed boulders for the alignment of circles and with dressed stone slabs for the orthostats chambers with its capstone. Urns were made out of Coarser Red ware and most of them are in completely broken condition. In the Cist burials dressed and undressed slabs are used for orthostats and cap stones. In this study area locally available raw materials for burials are of Proterozoic in age with types as granite, charnockite, granitic gneiss and dolerite. Granite is the dominating raw material used in the construction of Cist burials. The materials used for cairn-circles and cairn packing are granite, charnockite, granitic gneiss and dolerite. Quartz is the major stone type that was used for cairn packing.

\section{Local Mythology and Vandalism}

In the Pennagaram region, the Megalithic monuments, such as Cairn-circle and cists are known and called by the local people in various names such as Pandiyar Kuli' and "Pandavar Kuli". Locals have a belief that ancient people lived inside these 
burials and also they have a belief that dwarf humans lived in this burial, whom they called "Chittira Kullargal". Most of the burials in Pennagaram taluk have been vandalized (Fig. 2) due to this myth by the locals in search of precious metals and for precious stones within the burial.

\section{Typology}

In the study area, three major types of Megalithic burials were noticed, such as cairn circles, cairn circles with cist and cairn circles with an urn. Though most of the burials from the study area are Cairn-Circle, due to vandalism activity by the locals the structures in the form of cist and urns burials have been exposed, otherwise, the surface indication only indicates Cairn-circle.

\section{Cairn-Circle}

The Cairn-Circles are one of the most popular types of Megalithic burials which are commonly seen all over South India. Mostly Cairn-Circles were constructed out of irregular boulders; usually, the stone was arranged in a circle or oval shape with cairn packing in the centre (Fig. 3). The diameter and measurement of the Cairn-Circle may vary according to the contents and some of the circles are found with cist burials and some of them have urn burials. These types of burials are found in the villages like Ajjanahalli, Eriyur, Kurkampatti, Pattakarankottai, Periyavathalapuram, Sidumanahalli, Solapadi and Thanda.

\section{Cairn-Circle with Cist Burial}

The Cist is a box-like structure constructed by four orthostats and covered with a capstone. The cist burial noticed here are found to have been constructed with four granitic orthostat slabs in the form of a tub with a huge capstone placed over it (Fig. 2). Usually, they are found in single and multiple chambers. The eastern or northern orthostat has invariably a round port-hole at the centre. These Cists was roundly surrounded by boulders and filled with cairn packing. These types of Megalithic 
burials are exposed due to human vandalism in the villages like Ajjanahalli, Eriyur, Pattakarankottai and Solapadi.

\section{Cairn circle with an urn}

It is one of the most dominating burial practices found in South India. These urns are generally closed with a lid and protected by a capstone and cairn packing. The Urns are made mostly of Red Ware or Black-and-Red Ware of coarse fabric and are ill fired. The rim portion is thick and short. They often have a decoration on the neck portion. The size of the Urn may vary from region to region. These Urns are buried inside the stone circle then filled with cairn packing. These Urns are noticed in vandalized burials in the villages like Periyavathalapuram and Sidumanahalli (Fig. 4).

\section{Findings}

Systematic exploration conducted by the authors of this article has revealed 10 burial sites from this taluk. Initial plotting of these burials on the contour, geological and geomorphological maps few important aspects related to these burial sites have been brought to light and they are as follows:

- Contour maps have revealed that most of the burials were erected on an evaluation of $250 \mathrm{mts}$ Above Mean Sea Level (AMSL) and only two sites namely Periyavathalapuram and Thanda are noticed above $300 \mathrm{mts}$ AMSL (Fig. 5).

- Lithology map has revealed that all these burial sites were found in the Charnockitic region (Fig. 6). As most all the boulders of cairn-circles were made out of Charnockites, so, the availability of raw material might be a reason for the selection of this location by the Megalithic burial builders.

- The geomorphological map indicates that all the burials are associated with pediment and pediplain formation (Fig. 7). A pediment is usually a place where smaller sized stones are found and these smaller sized stones were used for cairn packing by the Megalithic builders and this could be the major reason why Megalithic builders have chosen this place. 
- A physical map indicates the water bodies of the study area have revealed that all the burial sites from the study area are located very near to river streams (Fig. 8). Water bodies are more important for rituals, so megalithic builders had chosen places very close to water bodies for erecting burials.

With the help of these maps, it could be concluded that the Megalithic builders of this region have preferred foot of the hills which are closer to an elevation of $250 \mathrm{mts}$ AMSL and preferred the pediment zone where they could easily find a smaller stone for cairn packing as all burials from this region are cairn-circles type burials.

\section{Conclusion}

Archaeological exploration conducted at this taluk has revealed 10 Megalithic burial sites with more than 10 burials from each site. Among the 10 Megalithic sites 3 sites namely Periyavathalapuram, Thanda and Sidumanahalli are almost destroyed. The destruction of Megalithic burials from Periyavathalapuram, Thanda and Sidumanahalli for treasure hunting is mainly due to the fact that the finding of Megalithic burials are in the deserted place, away from the present habitation and are situated in the Reserve Forest region. Irrespective, of the elevation of the landscape the Megalithic builder of this region preferred Cairn-Circle type burials. The site of Periyavathalapuram and Thanda has situated more than $300 \mathrm{mts}$ AMSL the burial types are the same. From all the vandalized burials, grave goods like the fine quality of Black-and-Red ware, All Black ware, Red Slipped and Red ware potsherds and some of these potsherds have graffiti marks on them were noticed. The associated finds with these burials in the form of potsherds indicate that these burials could be placed in a time frame from 1100 BCE to 500 BCE. As this article is based on initial systematic exploration works, more intensive exploration and excavation work would through much more valuable information on the Megaliths from this region. 


\section{Reference}

Gosh, A., (ed)., (1973). Indian Archaeology 65-66: A Review, Archaeological Survey of India, New Delhi.

Gosh, A., (ed)., (1989). An Encyclopedia of Indian Archaeology, Vol.2, Munishiram Manoharlal publishers.

Joshy, M. C., (ed)., (1993). Indian Archaeology 88-89: A Review, Archaeological Survey of India, New Delhi.

Lal. B.B., (ed)., (1973). Indian Archaeology 69-70: A Review, Archaeological Survey of India, New Delhi.

Mitra. D., (ed)., (1983). Indian Archaeology 79-80: A Review, Archaeological Survey of India, New Delhi.

Rajan. K., (ed)., (2009). Catalogue of Archaeological sites in Tamil Nadu Vol.1, Heritage India trust.

Sewell, Robert, (1882). Antiquarian Remains on the presidency of Madras, Oxford University Press.

Smiriti, H., (2013). Situating Megalithic burials in the Iron Age - Early historic landscape of southern India, Antiquity, Vol.87, pp.488-502. 


\section{Figures}

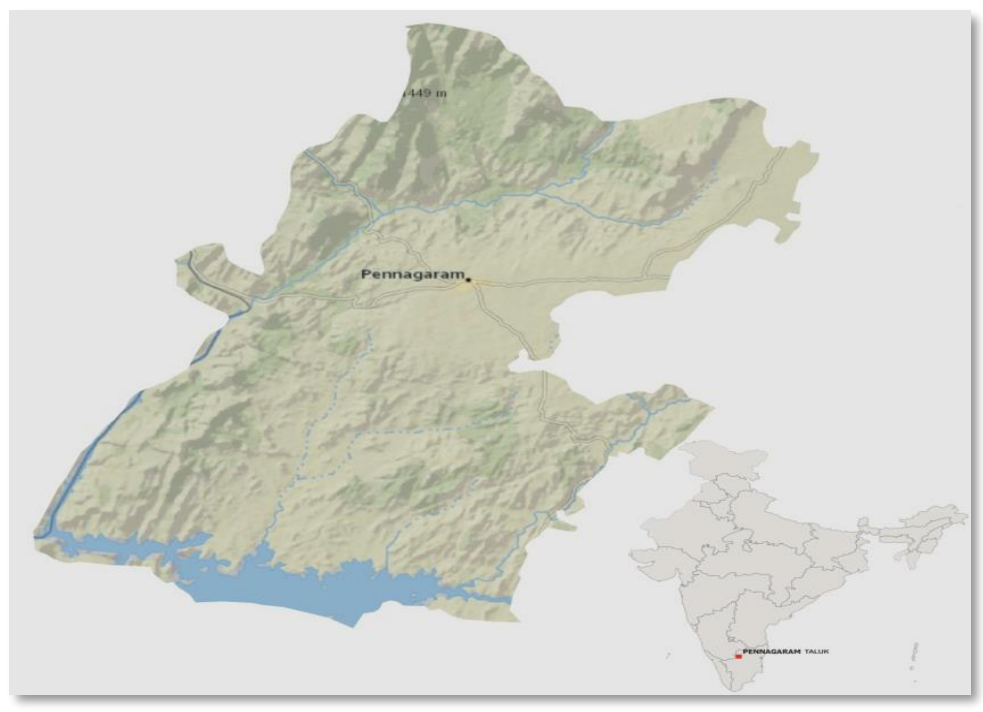

Figure 1. Study Area, Pennagaram Taluk, Dharmapuri District.

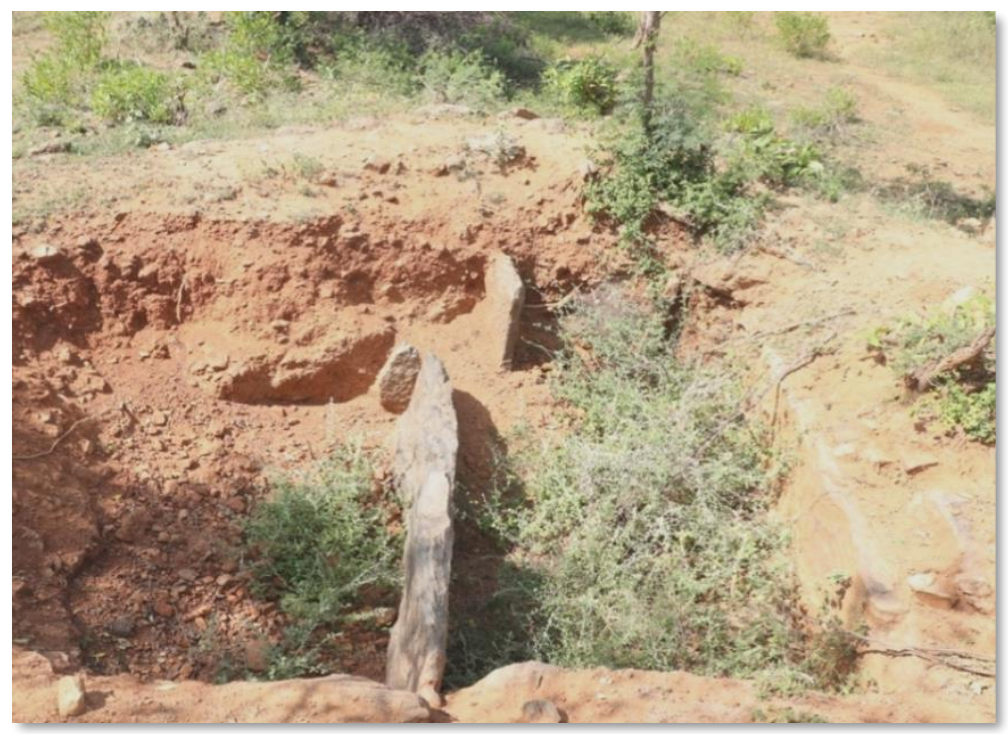

Figure 2. Vandalized Cist Burial from Tanda, Pennagaram Taluk. 


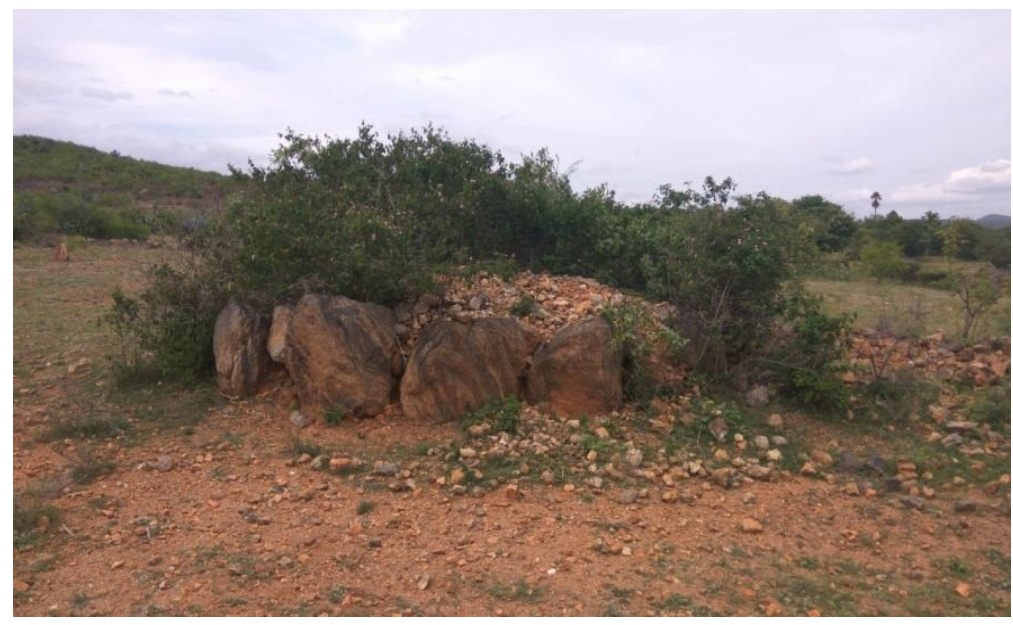

Figure 3. Cairn-Circle from Solappadi, Pennagaram Taluk.

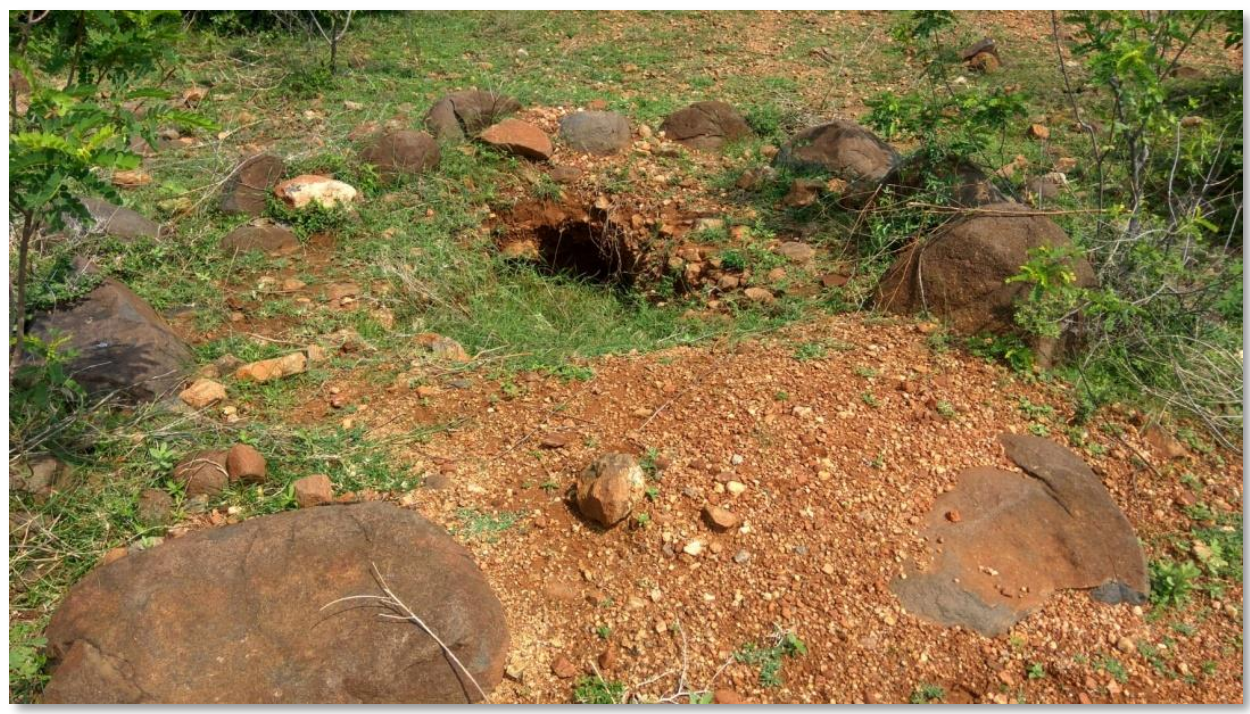

Figure 4. Vandalized Urn Burial from Sidumanahalli, Pennagaram Taluk. 


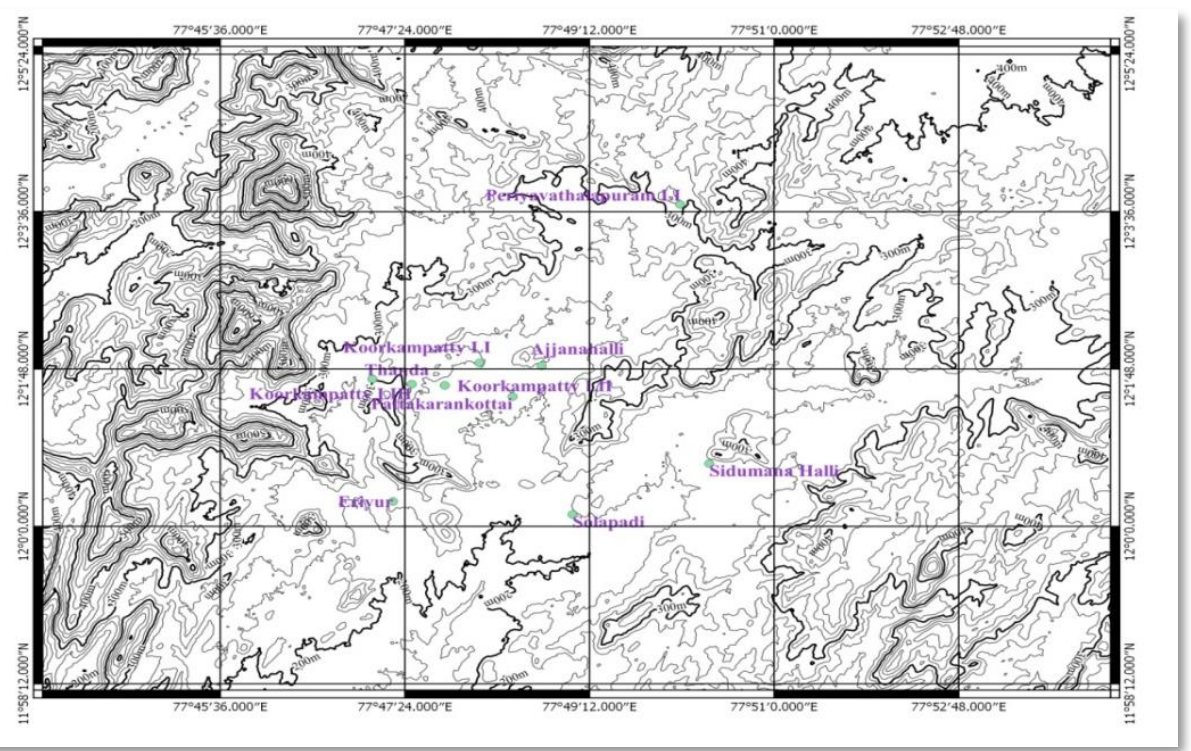

Figure 5. Contour map of the Study area.

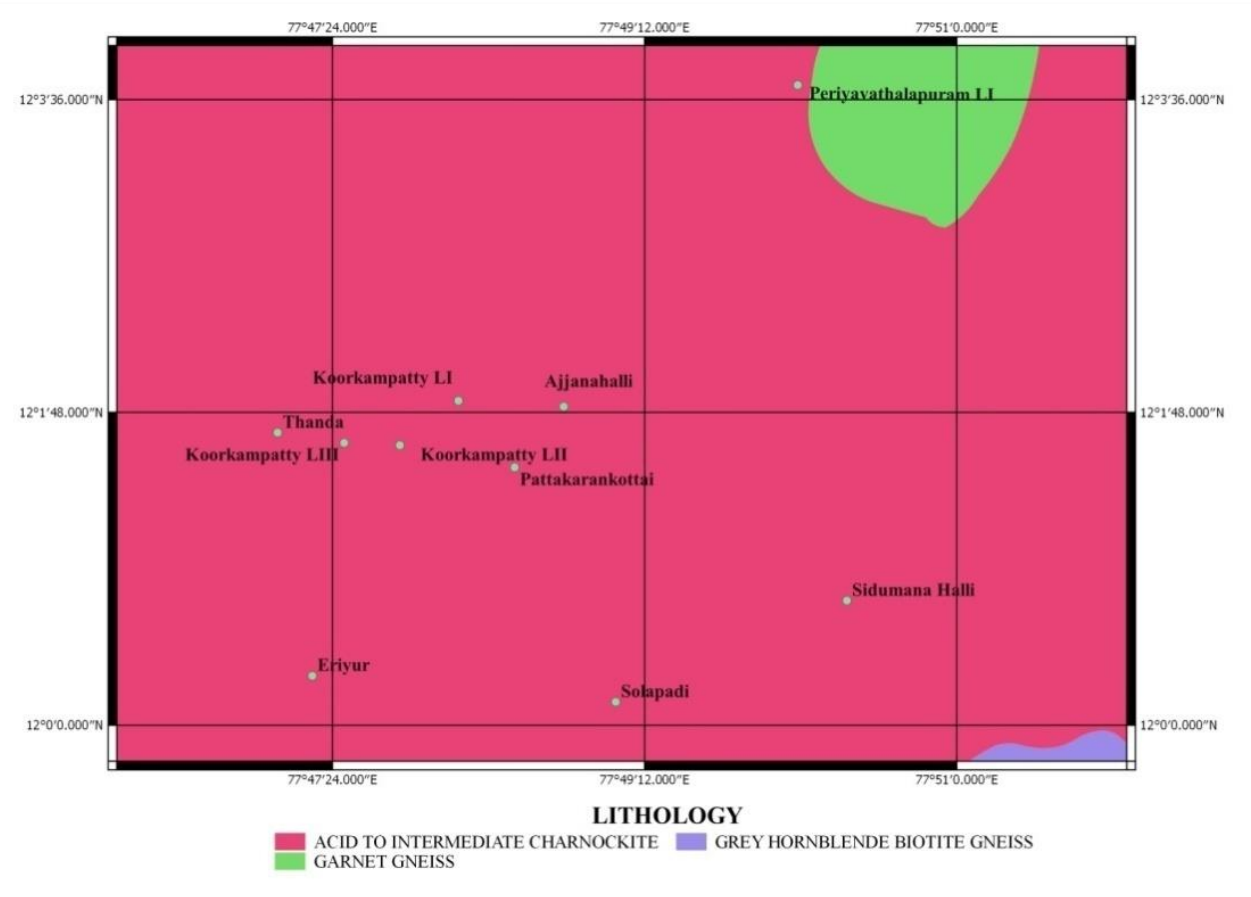

Figure 6. Lithology map of the Study area. 


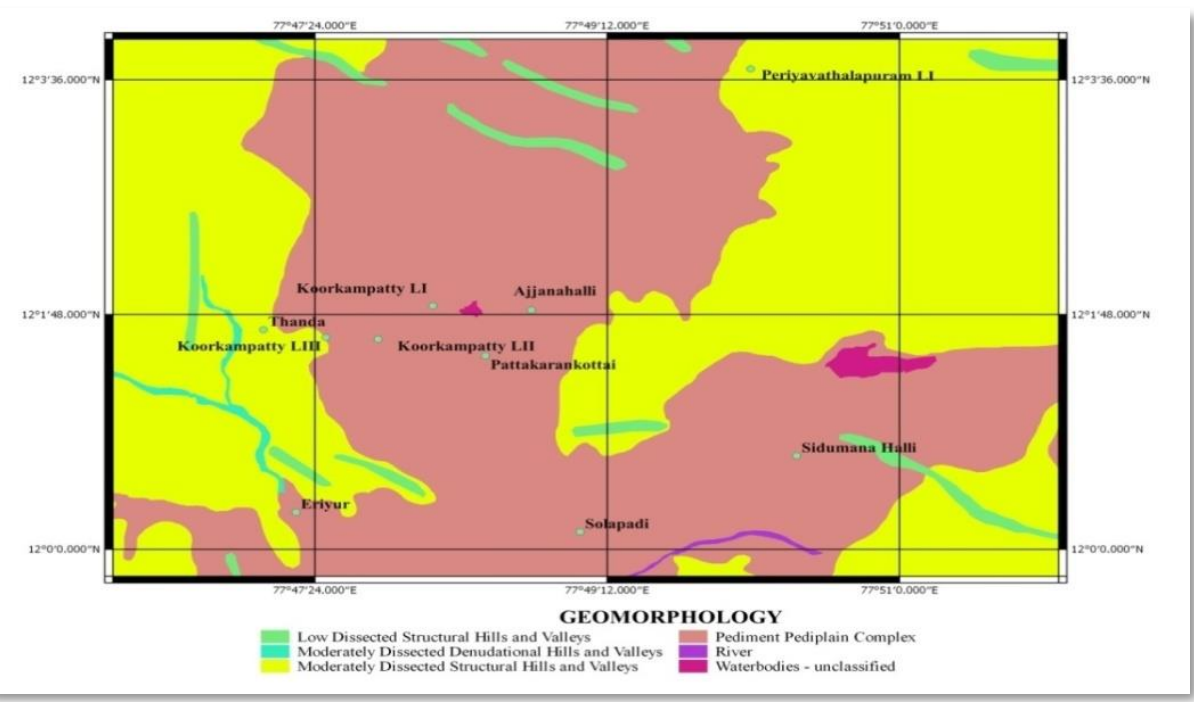

Figure 7. Geomorphology map of the Study area.

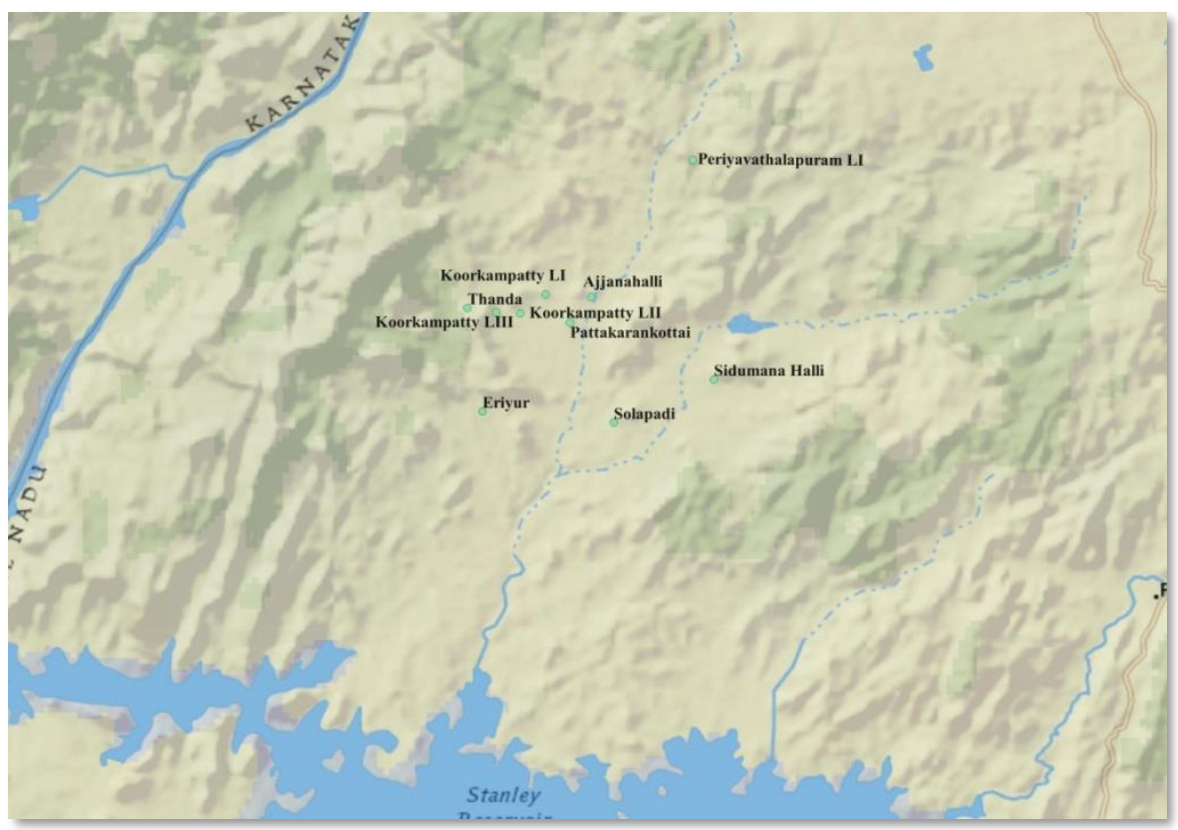

Figure 8. Physical map indicating water bodies of Study area. 